\title{
Heritage Street and Contemporary Use of Old Buildings in Johor
}

\author{
Wan Hashimah Wan Ismail \\ Department of Architecture, Faculty of Built Environment, \\ Universiti Teknologi Malaysia, Malaysia \\ wan7137shima@gmail.com
}

\begin{abstract}
This paper concerns the use of the buildings along a heritage street in Johor Bahru city centre in Malaysia. The fabrics of Johor Bahru city are in the phase of changing, similar to the other cities in the world. Parts of the city were already torn down and replaced by new buildings to meet the demands of the modern society. Some sections of the city were accepted as heritage area by the local authority. This includes a street known as Tan Hiok Nee Street. Both sides of the street are lined partly with rows of shop houses built in the early $20^{\text {th }}$ century. A preliminary study on the street indicated that it was not popular to the general public during the day time. It is often emphasized by scholars that the current and future uses of the old buildings are crucial to their survival. The usefulness of the existing buildings along the street was thus questionable. A research was then conducted to examine the current situation of the street especially in the use and the condition of the buildings. The intention was also to probe on the reasons why the street was not lively. The data was collected from site observation, literature review and interview of the tenants, owners as well as visitors. The analysis was based on these data from which the conclusions were drawn. It was found that part of the street was rather quiet with some of the shops hardly survived to meet ends. Some of the buildings were not in use and their condition revealed poor maintenance. The external area was already upgraded by the local authority. However, the condition of the area showed the lack of maintenance. The other reasons include the shifting of the residents, the lack of strong interest for the visitors, the lack of strong connectivity to the major nodes and the high rent. It is inevitable that the whole area needs a constant supervision. It also suggests that some of the buildings do not meet the current demands of the users. This may result in the removal of the buildings in the near future. Some strategies need to be devised in order to retain the heritage street for the benefit of the future generations.
\end{abstract}

Keywords: heritage; street; shophouses; Johor

eISSN 2514-751X @ 2018. The Authors. Published for AMER ABRA CE-Bs by e-International Publishing House, Ltd., UK. This is an open-access article under the CC BY-NC-ND license (http://creativecommons.org/licenses/bync-nd/4.0/). Peer-review under responsibility of AMER (Association of Malaysian Environment-Behaviour Researchers), ABRA (Association of Behavioural Researchers on Asians) and CE-Bs (Centre for EnvironmentBehaviour Studies), Faculty of Architecture, Planning \& Surveying, Universiti Teknologi MARA, Malaysia.

https://doi.org/10.21834/aje-bs.v3i11.331 


\subsection{Introduction}

This paper concerns the current use of the heritage buildings along a street in Johor Bahru city center in Malaysia. The fabrics of the city are in the phase of changing, similar to the other cities in the world. The local authority through Iskandar Region Development Authority (IRDA) had recognized some sections of the city to have heritage value and need to be revitalized. The main intention was to ensure the preservation of the historical and cultural aspects of the city. These elements were hoped to shape the characteristics of Johor Bahru and contribute to the economic activities that include the tourism industry.

There were 250 heritage buildings in the city, rich in history and culture (IRDA, 2013). The recognized heritage areas include a street known as Tan Hiok Nee Street. A preliminary study on the road indicated that it was not attractive to the general public during the day time. The usefulness of the existing buildings along the street to the contemporary users was thus questionable. It is often emphasized by scholars that the current and future uses of the heritage buildings are crucial to their survival. The research was conducted to examine the current situation of Tan Hiok Nee Street especially in the use and the condition of the buildings. The intention was also to probe on the reasons why the street was not popular among the visitors. The research aims to provide some feedback to continue retaining the heritage buildings along the street and the other buildings in the city.

\subsection{Literature Review}

\subsection{Streets and users}

The shop houses and the streets were the two principal elements of urban space in the older sections of the towns and cities in Malaysia. The earlier streets were built to accommodate the pedestrians and the earliest modes of transportation. The streets serve as the pedestrian network that links the various parts of a town. Lynch (1972) considers it is the pedestrian network that creates the human town rather than the traffic routes that cut through the town impersonally. The argument is in line with Tibbalds (2001) who sees the street as a connection to the buildings. According to him, the human contact and interaction extend from the street and other outdoor spaces into the buildings which enclose and line them. Thus, the street is not just a mere path but also an intermediate space before reaching any building. The grid-iron patterns of the streets could be the result of the division of building lots and building typology (Shuhana and Bashri, 2010).

The identity and character of shopping streets and other places are shaped by the physical elements, the activity, and the perceptual image. Norsidah (2010) notes that the physical attributes and characteristics have a strong influence on the degree of attachment. The identified key characteristics of the shopping streets are the strategic location, good accessibility, variety in accessibility, proximity to transport nodes, good connectivity, permeability, imageability, a clear sense of direction and identifiable nodes and place markers. These characteristic's components were used to compare with the findings of the research on the heritage buildings along Tan Hiok Nee Street. 
The popularity of street depends on the users. In a related research in the historic City of Malacca, the majority $(68.48 \%)$ of the users found that the spaces of the shop houses were comfortable for shopping activities. The reasons include the suitable arrangements of the merchandise (35.4\%), merchandise availability $(23.9 \%)$ and comfort in circulation within the interior (Wan Hashimah, 2010). These findings were also used to check on the current uses of the shop houses along Tan Hiok Nee Street.

\subsection{Tan Hiok Nee Street}

Tan Hiok Nee Street was constructed between 1910 and 1920 and runs perpendicular to Trus Street, the first modern road built in Johor Bahru. The street ended at the edge of the Segget River close to a market that was built on a triangular island reached by boat or by crossing a bridge. The market was later torn down, and the Segget River along Wong Ah Fook Street was reduced in size and covered.

At the turn of 21st century, Tan Hiok Nee Street became too crowded with the motor vehicles. The local authority initiated a few measures in 2004 to reduce the problems particularly after the recognition of the street as a heritage street. The upgrading includes the introduction of paved walkways that minimize the size of the road for vehicles. Some street furniture and landscape were also introduced to encourage people to pause within the area. The facades of the buildings along the street were also re-painted to enliven the area.

\subsection{Methodology}

The data was collected from site observation, literature review and unstructured interview of the users. The collection of data on the use of the building and the interview was done within two weeks. However, the observation of the activities along the street was done over a period of six months. This data was also compared to the data collected in the year 2000 to see the differences in building use over the years.

The collection of data was done both during the day and at night to see the differences in the utilization of all 65 buildings along the street. The respondents for the interview were picked at random. This involved 150 users consisting of 100 visitors and 50 residents or tenants. The time allocated for collecting the data for the research was from $8.00 \mathrm{am}$ to $10.00 \mathrm{am}, 12.00$ noon to $2.00 \mathrm{pm}, 4.00$ to $6.00 \mathrm{pm}$ and 8.00 to $10.00 \mathrm{pm}$. The number of visitors was counted daily according to the period. The analysis was done based on the whole data collected from site observation, literature review and interview of the users. Finally, the conclusions were drawn.

\subsection{Results}

\subsection{Building characters}

There were 65 building lots along the street and largely (66\%) consisting of pre-war (constructed before 1914) shophouses (Table 1). There were two outstanding buildings, 
namely the Toh Ah Boon's house and the Chinese Association Gallery. The other buildings have plain façades without any decorative elements. The majority of them consisted of 2storey shophouses. The other character was that the buildings were connected at the ground level by the continuous covered open corridors that give shelter to the pedestrians from the rain and sun.

Table 1: Building types along Tan Hiok Nee Street

\begin{tabular}{ll}
\hline Building styles & Number \\
\hline Pre-war shop houses & 43 \\
Modern shop houses & 17 \\
Modern high rise & 3 \\
Modern low rise & 2 \\
Total & 65 \\
\hline
\end{tabular}

\subsection{Building uses}

(Source: Author)

The primary uses of the buildings along the street were eateries (18.5\%) and retail stores $(18.5 \%)$. The eateries were the main attraction for the public at day time and six of them operated at night. Two of the night eateries did not open at day time due to lack of customers.

Comparing to the survey done in the year 2000 , the buildings that relate to services had reduced by $61.5 \%$. The types of shops that had closed down include clothes cleaning shop at No.53 and wholesale rice shop at No.62. The reason could be a reduction in demand of the residents or tenants around the area for those services.

There were only two shops selling cloth and one tailor shop along the street. According to history, the street was named after a fabric peddler turned Major China of Johor, Tan Hiok Nee, who had opened several textile shops there in the early days. Only 2 of the textile shops and one tailor shop remained along the street. It was observed that very few customers went to the clothes shop over the months of studying the street.

Table 2: Building use at ground floor level

\begin{tabular}{lccl}
\hline Building use & $\mathbf{2 0 0 0}$ & $\mathbf{2 0 1 4}$ & $\begin{array}{l}\text { In operation } \\
\text { at night }\end{array}$ \\
\hline Residential & 2 & 0 & 0 \\
Office & 7 & 4 & 0 \\
Education & 1 & 3 & 0 \\
Museum & 2 & 2 & 0 \\
Multi-purpose & 0 & 1 & 0 \\
Services & 13 & 5 & 1 \\
Bank & 4 & 4 & 0 \\
Eatery & 14 & 12 & 6 \\
Retail & 14 & 16 & 0 \\
Store & 0 & 3 & 3 \\
Parking & 2 & 2 & 0 \\
Not in operation & 0 & 13 & 0 \\
Total & $\mathbf{6 5}$ & $\mathbf{6 5}$ & $\mathbf{9}$ \\
\hline
\end{tabular}

The first row of shops (16 lots) along the street had double frontage. Some of the shops were operating from the other street known as Ibrahim Street. For these stores, Tan Hiok Nee 
Street was considered as the back lane. A new addition along the street was a cafeteria built at one side of the car park. It was made entirely of ship containers and enlivened the car park area.

As mentioned earlier, the street was already upgraded by the local authority. However, the condition of the area showed the lack of maintenance. Many of the shops had ceased in operation. When compared with the data collected in the year $2000,13(20 \%)$ of the buildings were not in used. The buildings which had recently closed down include three lots of restaurant at one end of the street.

From the interview of the tenants of another eatery, it was mentioned the possible cause for the closing of the shops in the area was the high rent. The owner of one of the eateries mentioned about having to pay for MYR2,000.00 per month which was considered small for the area. The other eatery nearby was rented at MYR3500.00 per month. The street was rather quiet at day time, and there were not enough customers who turned up at the eateries to cover the marginal operating cost.

\subsection{Visitors to the street}

There was a vast difference in the number of visitors along the street during the day and at night (Table 3). At daytime, it was found that part of the road was rather quiet with some of the shops without any customer. The focus of visitors was the eateries near the junction where Tan Hiok Nee Street meet Trus Street. Thus, the number of visitors increased during meal times (12.00noon to $2.00 \mathrm{pm}$ and 8.00 to $10.00 \mathrm{pm}$ ). The rest of the buildings along the street hardly got any customer. At times, there were street performers along the street and they enliven the street.

Table 3: Percentage of visitors according to time period

\begin{tabular}{lc}
\hline Time period & Percentage of visitors \\
\hline 8.00 to $10.00 \mathrm{am}$ & $06.7 \%$ \\
12.00 to $2.00 \mathrm{pm}$ & $20.0 \%$ \\
4.00 to $6.00 \mathrm{pm}$ & $06.7 \%$ \\
8.00 to $10.00 \mathrm{pm}$ & $66.7 \%$ \\
Total & $100 \%$ \\
\hline
\end{tabular}

Even though a proper parking area was provided at a particular area along the street, many people chose to park on the paved walkway. This violated the intention for the use of the sidewalk for the pedestrians only. The parked cars on the pavement hindered a good coverage of the street, particularly at the junctions. One accident was witnessed due to this factor during the study of the street.

One of the places that attracted visitors was Toh Ah Boon's house situated at the end of the top first row of the shophouses from the left (Figure 1). The Chinese Society rented this beautiful house, and it actively held events over the weekends. The activities include an art exhibition, items from recycling materials, and musical performance. Some activities continued through the night. 
From 7:00 pm onwards, the situation of the street changed drastically due to a night bazaar. This street and several others were closed to traffic. The vehicles were replaced by the hawkers or street vendors who displayed their merchandise either at the stalls, on the tables or simply on a spread. The stalls spread to Segget Street and up to Wong Ah Fook Street. The activities attracted a large crowd daily especially over the weekend $(66.7 \%)$. Only a few buildings operated at night along Tan Hiok Nee Street. Out of 65 lots of buildings, only $9(13.8 \%)$ buildings were opened at night, and 3 of them were used as storage space for the stalls of the night bazaar. The other six buildings were eateries.

Apart from the night bazaar, there were also activities organized by the Chinese Association. A big screen was placed at the roadside next to the Chinese Association Gallery to show dances and songs for karaoke. This activity attracted a crowd who either participated in the dancing or singing or to sitting around as audiences.

However, all these activities were very dependent on the weather and could take place only when the weather was beautiful. It was cooler at night and comfortable for the visitors to walk around the area for shopping or leisure. However, when it rained heavily no stalls were put up, and the street was empty.

\subsection{Discussions}

Comparing to the key characteristics of the shopping streets as highlighted by Norsidah (2010), an attractive street has a strategic location, excellent accessibility, variety in accessibility, permeability, imageability, a clear sense of direction, identifiable nodes and place markers. Tan Hiok Nee Street lacked 2 qualities that make it popular with the users. It was far from the transport nodes. The transport nodes in the city were close to City Square, a modern shopping complex. That was where a large crowd of people was found daily. The place was about 500 meters from Tan Hiok Nee Street.

Tan Hiok Nee Street also lacked a good connectivity from one major node to another. The node at the western end consisted of the public buildings namely the civil court, local authority building, and the post office. However, the street was not connected to another major node on the eastern end. In the past, the market was the major node at the eastern end of the street. Currently, the street ended with an open car park that did not seem to contribute directly to the street. The new buildings that replaced the market were not vibrant and attractive enough to serve as a node. The busy streets were the other factors that hindered pedestrians to walk freely. The streets were full with moving and parked vehicles during the day.

Comparing to the past research on shopping activities in the historic city of Malacca (Wan Hashimah, 2010), the shops along Tan Hiok Nee Street did not seem to have the qualities that appealed the local visitors or tourists. As mentioned earlier, the reasons for comfortable shopping include the suitable arrangements of the merchandise $(35.4 \%)$, merchandise availability $(23.9 \%)$ and ease in circulation within the interior. Most of the interior of the shops along Tan Hiok Nee Street were messy, and the merchandise sold was the necessities for the households that were not appealing to the visitors. 
The introduction of the night bazaar by the local authority enabled the street and the surrounding area to be lively at night. However, only a few of the tenants of the shops along Tan Hiok Nee Street benefited from this event. The popularity of the street was not because it was recognized as a heritage street and existence of the heritage buildings. The primary concern of the visitors was the goods sold at the night bazaar and the eateries. The crowd would shift if the night bazaar or the eateries moved to another area.

The other positive aspect was the closure of the streets involved in the night bazaar to the traffic as imposed by the local authority. This ruling enabled the visitors to park their vehicles outside the vicinity and walked freely from one street to another. The visitors were concerned for their safety while shopping along the street (Wan Hashimah, 2010).

\subsection{Conclusion}

The sustainability of the buildings in the area depends on the adaptability of the buildings to new uses. The other important aspect is heritage awareness among the owners and the controllers that include the local authorities and the higher authorities. It is inevitable that the whole area needs constant supervision and maintenance. The findings suggest that some of the buildings do not meet the current demands of the users. This situation may result in the removal of the buildings.

Thus, some strategies need to be devised to retain the heritage street for the benefit of the future generations. Suggestions include the building of a proper node on the western end of Tan Hiok Nee Street, a stricter control on parking to be imposed on the area and a change in the merchandise sold to be more appealing to the visitors. There should be a control on the rental price of the buildings along the area to ensure all the buildings are in use. The other suggestion is to arrange a proper schedule for street performances along the street that can attract visitors to the street during the day and at night.

In this research, only a street was covered. A similar analysis may be done on the other heritage streets. The next research could involve questionnaire survey on the users of the heritage streets. The intention is to seek their opinion on the street and the surrounding areas. The data can be used as part of the measures to ensure the continuous survival of the heritage streets and heritage buildings in Johor Bahru.

\section{Acknowledgement}

This study was made possible by the continuous support from Architecture Department of Universiti Teknologi Malaysia.

\section{References}

Iskandar Region Development Authority (2013). Vision the City Rejuvenation and Revitalisation Lab. 
Wan Ismail, W.H., / Asian Journal of Environment-Behaviour Studies (ajE-Bs), 3(11) Nov / Dec 2018 (p30-37)

Lynch, K. (1972). What Time is This Place. Cambridge, USA: Massachusetts Institute of Technology Press.

Norsidah Ujang (2010). Place attachment and continuity of urban place identity. Asian Journal of EnvironmentBehaviour Studies, 1, 2, 61-76.

Shuhana Shamsuddin \& Ahmad Bashri Sulaiman (2010). The street and its influence on the sense place of Malaysian cities. On Asian Streets and Public Space. (pp. 143-158). Singapore: National University of Singapore

Tibbalds F. (2001). Making People-Friendly Towns: Improving the public environment in towns and cities. London : Spon Express.

Year 4 (2000). Urban Study of Johor Bahru City Centre. Johor Bahru: Architecture Dept., Universiti Teknologi Malaysia.

Wan Hashimah Wan Ismail(2010). Users' perceptions of shopping activities in the historic city of Malacca. Asian Journal of Environment-Behaviour Studies, 1(3), 3-82. 